\title{
ОТДЕЛЬНЫЕ ПРОБЛЕМЫ ПЕНСИОННОЙ РЕФОРМЫ РФ И ВОЗМОЖНЫЕ ПУТИ ИХ РЕШЕНИЯ
}

\section{INDIVIDUAL PROBLEMS OF THE PENSION REFORM OF THE RUSSIAN FEDERATION AND POSSIBLE WAYS TO SOLVE THEM \\ N. Kuznetsova T. Matveeva}

Summary: The article contains an analysis of the most pressing problems of such an important institution of society as pension provision. The authors analyzed the direction of pension reforms in modern Russia. The problems in this area are identified, an attempt is made to assess them, and ways to solve them are proposed.

Keywords: pension, pension provision, pension reform, pension insurance.

\author{
Кузнецова Наталья Александровна \\ старший преподаватель, ФКОУ ВО «Владимирский \\ юридический институт ФСИН России» \\ kuz1503@yandex.ru \\ Матвеева Тамара Павловна \\ старший преподаватель, ФКОУ ВО «Владимирский \\ юридический институт ФСИН России» \\ matveeva33@mail.ru
}

Аннотация: Статья содержит анализ наиболее актуальных проблем, такого важного института общества как пенсионное обеспечение. Авторы проанализировали направление пенсионных реформ современной России. Определены проблемы в данной сфере, сделана попытка их оценки и предложены пути их решения.

Ключевые слова: пенсия, пенсионное обеспечение, пенсионная реформа, пенсионное страхование.

крайне обременительной для экономики страны, собственных средств, собранных с работодателей в виде страховых взносов, не хватает для обеспечения всех возложенных на ПФР обязательств, решать проблему приходится за счет дотаций федерального бюджета, но и в таком виде пенсионное обеспечение находится на низком уровне и не может обеспечить даже минимальные потребности подавляющего большинства пенсионеров.

Распад СССР, становление новой России ознаменовался целым комплексом социально-экономических проблем: жесткий экономический кризис, увеличение инфляции, разрыв экономических связей внутри страны и за ее пределами, безработица, снижение доходов населения, резкий спад рождаемости, который затянулся на довольно длительное время. Это привело к изменению в структуре возрастно-половой пирамиды, увеличивалось количество действующих и будущих пенсионеров, уменьшилось количество экономически активного населения. Провал рождаемости в 90- годах 20 века, а следовательно недостаточное количество работников не смогли бы в будущем при старой распределительной модели обеспечить потребности работающих, пенсионеров и детей, нетрудоспособное население будет преобладать по отношению к трудоспособному.

К сожалению, современной России, так и не удалось решить эти проблемы: длительный экономический кризис, отсутствие реального прироста средней заработной платы населения, уменьшение промышленного комплекса страны, утечка инвестиций и кадров из России, увеличение числа пенсионеров по отношению к количеству работающего населения, высокий уровень 
безработицы, в том числе вызванный коронавирусным кризисом.

Отсюда следует, что сформировавшийся на сегодняшний день кризис, вскоре, может привести к неспособности Пенсионного фонда России осуществлять выплаты пенсий за счет отчислений работодателей. На сегодняшний день увеличивается количество в стране самозанятых. А их отчисления в ПФР незначительные и это намного меньше чем отчисления работодателей за наемных работников. К тому же есть категории работодателей, которые выдавая зарплату в конвертах, вообще стараются уйти от налогообложения. Чтобы Пенсионный фонд страны пополнялся стабильно следует, возможно, искать источники для его нормального формирования.

Так как основным источником финансирования дефицита ПФР являются межбюджетные трансферты из федерального бюджета, то это может существенно ударить по экономике нашей страны, сформировать бюджетный дефицит, снизить финансирование пенсионной системы, привести к краху пенсионной системы, уменьшить и без того скромные пенсии.[4]

Данные трудности являлись одними из причин разработки и принятия новой пенсионной системы, решение которое нужно принять сейчас, а результат мы сможем оценить приблизительно к 2045 году, когда первые пенсионеры приобретут право на пенсию по новым правилам.

Попытки реформирования государственной пенсионной системы в РФ производились неоднократно.

В 2015 году федеральный закон № 400-Ф3 «О страховых пенсиях» продолжил начатые реформы. Как ранее было отмечено в РФ предусматривается два вида пенсий: страховая и накопительная. Средства пенсионных накоплений формируются в основном за счет страховых взносов, отчисляемых работодателями за наемных работников до 2014 года. Но с 2014 по 2019 год по решению государства новые поступления взносов от работодателей на пенсионные накопления были приостановлены. И в течении последующего года граждане формирующие накопительную пенсию могли сделать выбор отчислений между страховой и накопительной. С 2015 года была введена новая пенсионная формула, которая не связана ни с заработком работника, ни с трудовым стажем и включает в себя новые требования к продолжительности страхового стажа, т.е. постепенное увеличение этого показателя с 5 до 15 лет в 2024 году. Это кажется справедливым, так как стимулирует трудозанятость, и исключает начисление пенсии по старости фактически неработающим маргинальным слоям населения. Введение ИПК (индивидуальный пенсионный коэффициент, который рассчитывают исходя из стажа работника и начисленных страховых взносов) и его постепенный рост до 30 ежегодно. ИПК также назначается за социально-значимые периоды: прохождение срочной службы, уход за детьми, в т.ч. детьми-инвалидами и престарелыми гражданами старше 80 лет. Этот ИПК фактически заменил рублевый учет на бальный, что является непонятным для будущих получателей пенсий.[1]

В 2019 году вступила в действие следующая волна пенсионной реформы. Вызвана она была необходимостью увеличения количества работающего населения для предотвращения и компенсации проблем, вызванных крайне низким уровнем рождаемости в 90-х годах XX столетия. Увеличить количество работающих можно было двумя способами: предоставить детям право на раннюю трудовую деятельность (Трудовой Кодекс РФ разрешает заключать трудовой договор по общему правилу с 16 лет), но тогда мы лишим подростков возможности полноценно учиться, и повышение пенсионного возраста, женщинам до 60 лет, мужчинам до 65 лет. Это мера получила законодательное закрепление, была весьма непопулярна среди населения, т.к. коснулась прежде всего пенсионеров текущего периода.

Но в нашей стране в соответствии со статистикой смертности средняя продолжительность жизни составляет 72 года: мужчины живут в среднем 68,5 лет, женщины - 78,5 лет. Статистика показывает, что около 43\% мужчин не доживают до возраста 65 лет.[5]. Если обратиться к старой модели пенсионной реформы, то возраст выхода на пенсию был определен с учетом медицинской статистики.

Анализируя опыт стран-соседей, участников СНГ, видим, что практически все они вынуждены были увеличить возраст приобретения права на пенсию по старости (за исключением Узбекистана, который поставил этот вопрос, но пока не решил внести изменения в нормативные акты). Именно этот опыт нам наиболее интересен, т.к. все работники взрослого поколения имеют право на трудовой стаж, приобретенный на территории бывшего СССР.

По нашему мнению, данная пенсионная реформа является неоднозначной. С одной стороны она позволит увеличить бюджет страны, за счет увеличения числа работающих, что возможно может благоприятно отразиться и на увеличении пенсионных выплат. С другой стороны, данная реформа может быть губительной для приблизительно половины населения, так как качество жизни и условия труда (несоблюдение гигиены труда, переработки почти повсеместная практика, слабая система здравоохранения), а также экологическая обстановка не способствуют увеличению продолжительности жизни, развитие специфической безработицы населения предпенсионного возраста, особенно в маленьких и моногородах, где 
одно градообразующее предприятие, и работать в случае его остановки просто негде, и ко всему невысокая продолжительность жизни мужского населения.

Стоит учесть тот факт, что данная реформа способствует увеличению количества работающего населения за счет увеличения срока до выхода на пенсию, но при этом не предусматривает увеличение рабочих мест, закрепляя лишь положения, запрещающие увольнение лиц предпенсионного возраста. По нашему мнению, данная особенность может создать значительную проблему с трудоустройством, в том числе для молодежи и эффективностью выполняемого труда.

А ведь по прогнозам статистики количество пенсионеров будет увеличиваться: в 2025 году количество пенсионеров будет определяться почти в 45 млн.; к 2030 46,5 млн человек; в 2040 году- более 50 млн. человек; к 2050 году число пенсионеров составит приблизительно 52 млн. человек.[5]

Смеем предположить, что если бы эта реформа была проведена раньше, но была бы направлена на молодых людей, которые приобретали право на пенсию по новым правилам, общественный резонанс был бы меньше, а по-

\section{следствия мягче.}

Таким образом, пенсионная реформа может оказать положительное воздействие на экономику и на жизнь населения, если будут реализованы следующие условия:

- Наличие реального роста экономики;

- Реальный рост заработных плат;

- Увеличение количества рабочих мест;

- Улучшение условий жизни и труда;

- Улучшение экологической обстановки в стране.

- Данные условия приведут к:

- Увеличению продолжительности жизни;

- Повышению качества жизни;

- Созданию благоприятных условий для увеличения рождаемости.

Подводя итог вышесказанному, перечисленные проблемы требуют незамедлительного решения, ведь если будет найдено решение, то это будет способствовать значительному увеличению качества жизни населения, росту экономики, снизится негативное отношение населения к пенсионной реформе. Однако стоит учитывать тот факт, что данные задачи требуют поэтапного и незамедлительного решения. Хотя решение таких задач и оценка их эффективности может занять не один десяток лет.

\section{ЛИТЕРАТУРА}

1. Федеральный закон от 28 декабря 2013 г.№ 400-Ф3 «0 страховых пенсиях» // 0фициальный интернет-портал правовой информации (www.pravo.gov.ru) 30 декабря 2013 г.

2. Федеральный закон «0 трудовых пенсиях в Российской Федерации» от 17.12.2001 N 173-Ф3.

3. Соглашение о гарантиях прав государств-участников Содружества независимых государств в области пенсионного обеспечения от13 марта 1992 г. (Заключено в г. Москве 13.03.1992)

4. Кузнецова Н.А., Рябова 0.А., Рунов А.С. Актуальные проблемы реформирования пенсионной системы на постсоветском пространстве//Modern Science. 2020. № 5-2. C. 131-135.

5. https://rosinfostat.ru/

○ Кузнецова Наталья Александровна (kuz1503@yandex.ru), Матвеева Тамара Павловна (matveeva33@mail.ru). 